Articles

\title{
Aspect in the English language: a comparative analysis of form and meaning in traditional descriptive grammars
}

\author{
Aspecto em língua inglesa: uma análise comparativa da \\ forma e significado em gramáticas descritivas tradicionais
}

\author{
Adriana Lessa' \\ Maria das Graças Salgado²
}

\section{ABSTRACT}

Aspect in the English language has been described through different categories and terminologies, which might lead teachers and students into some misunderstandings. Considering the importance of understanding the systematic representation of this concept in learning a foreign language, we review and compare the various ways aspect is presented in five of the most traditional descriptive English grammar books. We examined whether aspect is explicitly approached; how it is defined; categorized and whether the types of aspect are clearly explained in terms of meaning. Based on that, we contrasted their classification and terminology with an alternative approach, highlighting ambiguities and common grounds.

Key-words: aspect; English grammar; classification; comparative analysis.

1. Doutora em Linguística, professora adjunta de Inglês do Departamento de Letras e Comunicação da Universidade Federal Rural do Rio de Janeiro (UFRRJ). Rio de Janeiro - Brasil. https://orcid.org/0000-0002-0637-0964. E-mail: adrianalessa@hotmail.com.

2. Doutora em Linguística, professora associada de Inglês do Departamento de Letras e Comunicação da Universidade Federal Rural do Rio de Janeiro (UFRRJ). Rio de Janeiro - Brasil. https://orcid.org/0000-0001-9370-3378. E-mail: mgssalgado@hotmail.com. 


\section{RESUMO}

O aspecto na língua inglesa tem sido descrito por meio de diferentes categorias e terminologias, o que pode gerar mal-entendidos para professores e estudantes. Considerando a importância da representação sistemática desse conceito na aprendizagem de uma língua estrangeira, este artigo revisa e compara as formas variadas como Aspecto é apresentado em cinco das mais tradicionais gramáticas descritivas do inglês. Analisamos, assim, se aspecto é explicitamente abordado; como é definido; categorizado e se os tipos de aspecto são claramente explicados em termos de significado. Com base nessa análise, contrastamos suas classificações com uma abordagem alternativa, esclarecendo ambiguidades e consensos.

Palavras-chave: aspecto; gramática do inglês; classificação; análise comparativa.

\section{Introduction}

Time can be considered a universal concept related to the way situations are measured or perceived. Due to its universal characteristic, this concept is linguistically represented worldwide. Although this linguistic representation may vary - from lexical to grammatical words, morphemes and particles -, many spoken languages express time recurring to tense and aspect markers, which play a major role in foreign language teaching and learning. In the present paper, we will focus on aspect markers in English, considering the international relevance of this language as a lingua franca.

Bearing in mind the importance of understanding the systematic representation of tense and aspect to the learning of a foreign language, this article aims to review and compare the various ways aspect is presented in some English grammar books. This analysis is justified by the recognition of concurrent classes and terminology in the description of this linguistic phenomenon. So, we contrast the categorization offered by traditional descriptive grammar books with an alternative approach represented by studies primarily concerned with meaning.

Thus, this paper is organized in two sections. In the first section, we present an overview on how aspect is approached in five of the 
most prestigious English grammar books adopted at universities around the world. In the second section, we compare the main definitions and categories provided by these grammar books at the perspective found in the renowned Bernard Comrie's Aspect: an Introduction to the study of verbal aspect and related problems.

\section{Section 1 - Aspect in English grammar books}

In this section, 5 (five) English grammar books are analyzed: Collins COBUILD English Grammar, by Collins (2005); Cambridge Grammar of English: a comprehensive guide, by Carter \& McCarthy (2006); The Oxford English Grammar, by Greenbaum (1996); A grammar of Contemporary English, by Quirk et al (1980) and Longman Grammar of Spoken and Written English, by Biber et al (1999). In order to compare more accurately the notions of aspect presented by the authors, we examine in table I: (a) whether aspect is explicitly approached; (b) how it is defined; (c) how it is categorized and (d) whether the types of aspect are clearly explained in terms of meaning.

Table I - Descriptive traditional grammars

\begin{tabular}{|c|c|c|c|c|}
\hline \multicolumn{5}{|c|}{ Analysis of English Grammar Books } \\
\hline $\begin{array}{l}\text { Title and } \\
\text { authorship }\end{array}$ & $\begin{array}{l}\text { Does it explicitly } \\
\text { approach } \\
\text { aspect? }\end{array}$ & $\begin{array}{l}\text { How does it define } \\
\text { aspect? }\end{array}$ & $\begin{array}{l}\text { How does it } \\
\text { categorize } \\
\text { aspect in } \\
\text { English? }\end{array}$ & $\begin{array}{l}\text { Are the } \\
\text { types of } \\
\text { aspect } \\
\text { clearly } \\
\text { explained } \\
\text { in terms of } \\
\text { meaning? }\end{array}$ \\
\hline $\begin{array}{l}\text { Collins } \\
\text { COBUILD } \\
\text { English } \\
\text { Grammar - } \\
\text { Collins (2005) }\end{array}$ & $\begin{array}{l}\text { No. It only covers } \\
\text { tenses and other } \\
\text { time expressions. }\end{array}$ & - & - & - \\
\hline $\begin{array}{l}\text { Cambridge } \\
\text { Grammar of } \\
\text { English - } \\
\text { Carter \& } \\
\text { McCarthy (2006) }\end{array}$ & $\begin{array}{l}\text { Yes. There is a } \\
\text { section dedicated } \\
\text { to "Verb phrase: } \\
\text { tense and aspect. }\end{array}$ & $\begin{array}{l}\text { "Aspect refers to the } \\
\text { speaker's/writer's } \\
\text { perspective on the time } \\
\text { of an event. In English, } \\
\text { aspect is concerned } \\
\text { mainly with how the } \\
\text { speaker perceives the } \\
\text { duration of events, and } \\
\text { how different events } \\
\text { relate to one another in } \\
\text { time." (p. } 411 \text { ) }\end{array}$ & $\begin{array}{l}\text { Two aspects: } \\
\text { progressive } \\
\text { (sometimes } \\
\text { called } \\
\text { continuous) } \\
\text { aspect and } \\
\text { perfect }\end{array}$ & Yes. \\
\hline
\end{tabular}




\begin{tabular}{|c|c|c|c|c|}
\hline $\begin{array}{l}\text { Title and } \\
\text { authorship }\end{array}$ & $\begin{array}{l}\text { Does it explicitly } \\
\text { approach } \\
\text { aspect? }\end{array}$ & $\begin{array}{l}\text { How does it define } \\
\text { aspect? }\end{array}$ & $\begin{array}{l}\text { How does it } \\
\text { categorize } \\
\text { aspect in } \\
\text { English? }\end{array}$ & $\begin{array}{l}\text { Are the } \\
\text { types of } \\
\text { aspect } \\
\text { clearly } \\
\text { explained } \\
\text { in terms of } \\
\text { meaning? }\end{array}$ \\
\hline $\begin{array}{l}\text { The Oxford Eng- } \\
\text { lish Grammar - } \\
\text { Greenbaum } \\
\text { (1996) }\end{array}$ & $\begin{array}{l}\text { Yes. It offers a } \\
\text { section named } \\
\text { "Verb Phrases" in } \\
\text { a chapter called } \\
\text { "The Grammar of } \\
\text { Phrases". There } \\
\text { is a subsection } \\
\text { called "Tense and } \\
\text { Aspect." }\end{array}$ & $\begin{array}{l}\text { "The aspect of the verb } \\
\text { refers primarily to the } \\
\text { way that the time of the } \\
\text { situation is regarded } \\
\text { rather than its location } \\
\text { in time in absolute } \\
\text { terms. The aspects are } \\
\text { expressed by a combi- } \\
\text { nation of an auxiliary } \\
\text { and a following verb." } \\
\text { (p. } 253 \text { ) }\end{array}$ & $\begin{array}{l}\text { Two aspects: } \\
\text { the perfect } \\
\text { aspect and the } \\
\text { progressive (or } \\
\text { continuous) } \\
\text { aspect. }\end{array}$ & Yes. \\
\hline $\begin{array}{l}\text { A Grammar of } \\
\text { Contemporary } \\
\text { English - } \\
\text { Quirk et al } \\
\text { (1980) }\end{array}$ & $\begin{array}{l}\text { Yes. It offers a } \\
\text { chapter named } \\
\text { "The Verb } \\
\text { Phrase", with a } \\
\text { section entitled } \\
\text { "Time, tense } \\
\text { and aspect," that } \\
\text { distinguishes } \\
\text { these concepts } \\
\text { and a subsection } \\
\text { dedicated to } \\
\text { Aspect. }\end{array}$ & $\begin{array}{l}\text { Aspect refers to the } \\
\text { manner in which the } \\
\text { verb action is regarded } \\
\text { or experienced. The } \\
\text { choice of aspect is } \\
\text { a comment on or a } \\
\text { particular view of the } \\
\text { action. (p. 91) }\end{array}$ & $\begin{array}{l}\text { Two sets of } \\
\text { aspectual } \\
\text { contrasts: } \\
\text { perfective/ } \\
\text { non-perfective; } \\
\text { progressive/non- } \\
\text { progressive. }\end{array}$ & Partially. \\
\hline $\begin{array}{l}\text { Longman Gram- } \\
\text { mar of Spoken } \\
\text { and Written } \\
\text { English - } \\
\text { Biber et al (1999) }\end{array}$ & $\begin{array}{l}\text { Yes. There is a } \\
\text { chapter called } \\
\text { "Variation in } \\
\text { the verb phrase: } \\
\text { tense, aspect, } \\
\text { voice, and } \\
\text { modality", with } \\
\text { a section entitled } \\
\text { "Aspect". }\end{array}$ & $\begin{array}{l}\text { "(...) aspect relates to } \\
\text { considerations such as } \\
\text { the completion or lack } \\
\text { of completion of events } \\
\text { or states described by a } \\
\text { verb." (p. } 460)\end{array}$ & $\begin{array}{l}\text { Unmarked/ } \\
\text { simple, perfect, } \\
\text { progressive (e.g. } \\
\text { v. sees v. Has } \\
\text { seen v. Is see- } \\
\text { ing) or perfect } \\
\text { progressive } \\
\text { (e.g. v. has been } \\
\text { seeing) (p. } 452 \text { ), } \\
\text { although the sec- } \\
\text { tion dedicated } \\
\text { to Aspect only } \\
\text { mentions the } \\
\text { perfect and the } \\
\text { progressive } \\
\text { aspects. }\end{array}$ & Partially. \\
\hline
\end{tabular}

In a first and more general analysis, considering the first question, it is important to highlight that aspect is a pervasive topic in these English grammar books, except for Collins (2005) - which does not even mention the topic. The other four references explicitly mention aspect in the title of the chapter related to verb forms or dedicate a 
section/subsection to introduce aspect. It is also relevant to register that all of them offer a fair amount of genuine examples of modern English usage and accomplish their aims of presenting the existing English verb forms.

Regarding the second question, within the four grammar books in which aspect is approached, we can find a definition of aspect related to the way speakers view, experience or regard a situation in Carter \& McCarthy (2006), Greenbaum (1996) and Quirk et al (1980). As for Biber et al (1999), a different definition of aspect is presented, relating it to the idea of completion of an event.

Despite the fact that all the books offer a generous explanation on aspect, Quirk et al (1980) can be considered the most comprehensive presentation in terms of examples and sections dedicated to the subject. Nevertheless, Greenbaum (1996) is the author who most evidently contrasts tense to aspect, providing a better understanding of the distinction between these two linguistic phenomena and the relationship between the concept of time and aspect. According to the author, tense is a grammatical category referring to the location of a situation in time, accomplished through a verb inflection, and "strictly speaking, English has only two tenses": present and past (GREENBAUM, 1996, p. 253). On the other hand, aspect relates to the way the time of the situation is viewed (see Table I).

Besides, the author is the only one who relates aspect to a specific verb form, which would be the combination of an auxiliary and a following verb. So, the progressive would be the result of the combination of the auxiliary be + -ing (e.g. is playing) and the perfect aspect would result from the combination of auxiliary have $+-e d$ (e.g. has played) (cf. GREENBAUM, 1996, p. 246).

Concerning the third question, in terms of aspect categorization, the authors tend to characterize the classes of aspect in a similar approach. Carter \& McCarthy (2006), Greenbaum (1996) and Biber et al (1999) assert that there are two 'aspects' in English, whereas Quirk et al (2005) expand the discussion, referring to 'two sets of aspectual contrasts' (see Table I). 
In spite of that, most of the authors arrange aspect in two categories: the progressive and the perfect aspect. It is worth mentioning that Biber et al (1999) introduce the existence of a so-called 'unmarked/ simple aspect', which is, however, overlooked in the section dedicated to aspect (see Table I).

Quirk et al (2005) deviate from this reductive division of aspect, presenting two sets of aspectual contrasts. The aspectual contrasts perfective versus non-perfective and progressive versus non-progressive can be considered a more elaborate categorization, as illustrated by the examples in Table II. In this perspective, there would be a system of complex verb phrases allowing the combination of perfective and progressive aspects. Although the authors do not explain what the non-perfective and non-progressive situations would be, they propose that these aspects be combined in various ways, which are reproduced in the following table.

Table II - System of contrasts in the complex verb phrase (Quirk et al, 2005:90 - adapted from the original by the authors)

\begin{tabular}{|l|l|l|l|}
\hline Symbol & Name & Example & Aspectual contrast \\
\hline Type B & $\begin{array}{l}\text { present perfect } \\
\text { past perfect }\end{array}$ & $\begin{array}{l}\text { he has examined } \\
\text { he had examined }\end{array}$ & $\begin{array}{l}\text { perfective } \\
\text { non-progressive }\end{array}$ \\
\hline Type C & $\begin{array}{l}\text { present progressive } \\
\text { past progressive }\end{array}$ & $\begin{array}{l}\text { he is examining } \\
\text { he was examining }\end{array}$ & $\begin{array}{l}\text { non-perfective } \\
\text { progressive }\end{array}$ \\
\hline Type BC & $\begin{array}{l}\text { present perfect progressive } \\
\text { past perfect progressive }\end{array}$ & $\begin{array}{l}\text { he has been examining } \\
\text { he had been examining }\end{array}$ & $\begin{array}{l}\text { perfective } \\
\text { progressive }\end{array}$ \\
\hline
\end{tabular}

In the authors' original table, the neutral aspects mentioned (i.e. non-perfective and non-progressive) are not properly explained. Nonetheless, we complemented it, as presented in the Table II, making explicit our assumptions that the verb forms of Type B (present perfect and past perfect) would be considered perfective and nonprogressive forms. Verb forms of Type $\mathrm{C}$ (present progressive and past progressive) would be non-perfective and progressive forms. Finally, verb forms of Type BC (present perfect progressive and past perfect progressive) would be the combination of both perfective and progressive aspects. 
So, although Quirk et al (1995) attempted to escape from the common-sense categorization of aspect, their complex classification does not fulfill its initial promise, since they have kept a strongly form-oriented approach. Furthermore, one interesting observation is that the class the authors name as 'perfective' is equivalent to the one referred to as 'perfect' aspect by the other authors. This is a difference in terminology we intend to develop in the next section.

Regarding the last question, the types of aspect seem to be clearly explained in terms of meaning in all the grammar books. The progressive aspect is related to the idea of temporariness or extended duration of an event. The perfect aspect is associated with the relationship between two time frames or the relevance of a situation (see examples in Table 1).

In general terms, Carter \& McCarthy (2006) provide the most thorough description and explanation of the aspectual classes regarding meaning. Nevertheless, Biber et al (2005) offer a comprehensive perspective in terms of illustration and distribution of these forms across registers and dialects, which cannot be found in the other grammar books. This can be confirmed by an examination on Table III, which summarizes the main explanations present in each grammar book.

Table III - Explanations on the types of aspect and examples in each grammar book

\begin{tabular}{|c|c|c|}
\hline \multirow{2}{*}{ Grammar book } & \multicolumn{2}{|c|}{ Explanations and Examples } \\
\hline & PROGRESSIVE ASPECT & PERFECT ASPECT \\
\hline $\begin{array}{l}\text { Cambridge } \\
\text { Grammar of } \\
\text { English - } \\
\text { Carter \& } \\
\text { McCarthy (2006) }\end{array}$ & $\begin{array}{l}\text { With the progressive aspect, the focus is } \\
\text { principally on the duration of the event. } \\
\text { It may therefore be used to indicate } \\
\text { that something is ongoing, unfinished, } \\
\text { or that it is extended but temporary. It } \\
\text { may indicate that something is/was/ } \\
\text { will be in progress when something else } \\
\text { happens/happened. In other words, the } \\
\text { focus is not on the starting or finishing } \\
\text { point of an event, but on the event as } \\
\text { seen from its centre. (p. } 412 \text { ) } \\
\text { Examples: } \\
\text { Why is he smiling like that? (present } \\
\text { tense) } \\
\text { Why was he smiling like that? (past } \\
\text { tense) }\end{array}$ & $\begin{array}{l}\text { Perfect aspect is concerned with } \\
\text { the speaker's perspective on the } \\
\text { relationship between one time frame } \\
\text { and an event that takes place in } \\
\text { another time frame. An event which } \\
\text { took place in the past may be seen } \\
\text { as relevant to the present moment. } \\
\text { Likewise, an event due to take place in } \\
\text { the future may be seen as linked to the } \\
\text { present moment. (p. } 415 \text { ) } \\
\text { Examples: } \\
\text { They have changed the time. (have } \\
\text { is present) } \\
\text { They had changed the time. (had is } \\
\text { past) }\end{array}$ \\
\hline
\end{tabular}




\begin{tabular}{|c|c|c|}
\hline \multirow{2}{*}{ Grammar book } & \multicolumn{2}{|c|}{ Explanations and Examples } \\
\hline & PROGRESSIVE ASPECT & PERFECT ASPECT \\
\hline $\begin{array}{l}\text { The Oxford } \\
\text { English } \\
\text { Grammar - } \\
\text { Greenbaum } \\
\text { (1996) }\end{array}$ & $\begin{array}{l}\text { The progressive aspect primarily } \\
\text { focuses on the duration of the situation. } \\
\text { (p. } 254) \\
\text { Example: } \\
\text { I have written many times before now. }\end{array}$ & $\begin{array}{l}\text { The perfect aspect is primarily used to } \\
\text { place the time of one situation relative } \\
\text { to the time of another situation. } \\
\text { Example: } \\
\text { I am writing a letter to my parents. }\end{array}$ \\
\hline $\begin{array}{l}\text { A Grammar of } \\
\text { Contemporary } \\
\text { English - } \\
\text { Quirk et al } \\
(1980)\end{array}$ & $\begin{array}{l}\text { "Progressive aspect indicates } \\
\text { temporariness - an action in progress } \\
\text { instead of the occurrence of an action } \\
\text { or the existence of a state." (p. 92) } \\
\text { Examples: } \\
\text { Joan is singing well. } \\
\text { Joan was singing well. }\end{array}$ & $\begin{array}{l}\text { "The present perfect indicates a } \\
\text { period of time stretching backwards } \\
\text { into some earlier time. It is past with } \\
\text { 'current relevance'. (...) The choice } \\
\text { of perfective aspect is associated with } \\
\text { time-orientation and consequently alse } \\
\text { with various time-indicators (lately, } \\
\text { since, so far, etc)." (p.91) } \\
\text { "The past perfect has the meaning of } \\
\text { past-in-the-past." (p.92) } \\
\text { Examples: } \\
\text { John has lived in Paris for ten years. } \\
\text { His sister has been an invalid all her } \\
\text { life (i.e. she is still alive). } \\
\text { For generations, Nepal has produced } \\
\text { the world's greatest soldiers (i.e. the } \\
\text { nation of Nepal must stilll exist). } \\
\text { Peter has injured his ankle but now it's } \\
\text { still bad. } \\
\text { John had lived in Paris for ten years } \\
\text { (when I met him). }\end{array}$ \\
\hline $\begin{array}{l}\text { Longman } \\
\text { Grammar of } \\
\text { Spoken and } \\
\text { Written English - } \\
\text { Biber et al (1999) }\end{array}$ & $\begin{array}{l}\text { "The progressive aspect designates } \\
\text { an event or state of affairs which is in } \\
\text { progress, or continuing, at the time in- } \\
\text { dicated by the rest of the verb phrase." } \\
\text { (p. } 460 \text { ) } \\
\text { Examples: } \\
\text { Progressive aspect present tense } \\
\text { I'm looking for an employee of yours. } \\
\text { (Fiction) } \\
\text { Progressive aspect past tense } \\
\text { I was just coming back from Witham. } \\
\text { (Conversation) }\end{array}$ & $\begin{array}{l}\text { "The perfect aspect designates events } \\
\text { or states taking place during a period } \\
\text { leading up to the specified time." (p. } \\
460 \text { ) } \\
\text { Examples: } \\
\text { Perfect aspect present tense } \\
\text { We have written to Mr Steven, but he } \\
\text { has ignored our letters (News) } \\
\text { Perfect aspect past tense } \\
\text { He had seen him picking purses } \\
\text { (Fiction) }\end{array}$ \\
\hline
\end{tabular}

\section{Section 2 - Comparison to an alternative perspective} on aspect

In this section, we offer an alternative perspective on aspect, based on Bernard Comrie's handbook named Aspect: an Introduction 
to the study of verbal aspect and related problems ${ }^{3}$. But, firstly, it must be emphasized that this peculiar characterization we adopt in this paper - calling Comrie's Aspect 'alternative' - is due to the fact that its comparative character sheds light on the meaning that underlies the different linguistic forms across languages.

In other words, Comrie (1976) presents the different aspectual meanings that might (or might not) be morphologically realized in various languages. In contrast, traditional descriptions of the English language usually offer restrict conceptual explanations induced by the linguistic forms adopted in such languages. Thus, Comrie's perspective on aspect may be approached as an alternative one when compared to explanations on aspectual meanings based exclusively on the English verb forms.

Nevertheless, although this perspective is portrayed as alternative in this paper, this typological study is recognized as a reference in different linguistic areas, since it pioneered comparative studies on aspect. Acknowledging that, we intend to establish a comparison between this benchmark and the different points of view offered by the traditional English grammar books. In order to do so, we recall two out of the four questions that guided the analysis presented in section 1: 'how is aspect defined?'; 'how is it categorized and explained in terms of meaning?'.

Considering how aspect is defined, Comrie (1976:3) states that the general definition of aspects could be formulated as "different ways of viewing the internal temporal constituency of a situation." We can observe that this definition coincides to most of the grammar books, since the authors have defined aspect as the way speakers view, experience or regard a situation (see Table I), except for Biber et al (1999) who relates aspect to the notion of completion as opposed to the lack of completion of events.

Although aspect's connection to time is self-evident, Comrie (1976) makes it explicit that aspect would be related to time in a different way

3. The focus on a single author favors a comparative analysis to the plurality of English grammar books selected. Nonetheless, it is worth highlighting that Comrie's points of view presented in this paper are in line with other cross-linguistic studies in the field. e.g. Dahl (1985) and Smith (1991). 
when compared to tense. Since Greenbaum (1996) dedicated some space to detail this distinction between Tense and Aspect, it is worth comparing his explanation to Comrie's proposal on that.

According to the latter, tense is a deictic category, since it locates situations in time with reference to the present moment or the time of other situations. Aspect is rather concerned with the internal constituency of the one situation it refers to. This difference might be illustrated by the following examples in various languages:
a) English: John was reading when I entered.
b) French: Jean lisait quand j'entrai.
c) Spanish: Juan leía cuando entré.
d) Portuguese: João estava lendo / lia quando eu entrei. ${ }^{4}$

In these sentences, the second verb - in bold type - introduces the main event that would have as a background the situation expressed by the first verb - which is underlined. Considering this example, Comrie (1976:5) states that "the different forms do serve a deictic function of locating my entry internally to John's reading," but this deictic function, related to tense, would be a "secondary consequence of the different ways in which they view the internal constituency of the situations referred to," which would be related to aspect.

This explanation on tense and aspect is in line with Greenbaum's (1996) definitions in terms of meaning. However, in terms of structure, Greenbaum associates aspect to compound verb forms, through the combination of main and auxiliary verbs, as previously indicated in Section 1. In Comrie's alternative perspective, tense and aspect are notions that might be present in compound or simple verb forms. This means that, differently from Greenbaum's proposal, the English simple verb forms would also convey aspect, expressing some of the aspectual semantic distinctions, other than perfect and progressive aspects, which shall soon be presented. So, the English Simple Past (e.g. entered) and Simple Present (e.g. enter(s)) would express tense, but they would also

4. Comrie (1976:3) presents these examples, except for the ones in Brazilian Portuguese, which have been offered by the authors of the present paper. 
express aspect. As we can see, this assumption represents an important distinction in the way aspect is regarded as a linguistic phenomenon, changing from a form-oriented to a meaning-oriented paradigm of aspectual classes.

The verbs "to read" and "to enter," inflected in the former examples ( $a$ to $d$ above) might help us understand the basic aspectual semantic distinctions proposed by Comrie. The difference between these verbs in the sentence would be that the second verb (i.e. entered) presents the totality of the situation (the entry), as a single unanalyzable whole, while the first one (i.e. was reading) makes explicit reference to the internal temporal constituency of the situation, since it refers to an internal portion of John's reading. This, in terms of aspect, would mean that the second verb has perfective meaning and the first verb has imperfective meaning. Although none of the English grammar books have mentioned this distinction between perfectivity and imperfectivity, Biber et al (1999) seems to refer to it, when relating aspect to completion or lack of completion of events (see Table I).

This perfective or imperfective point of view guides the basic categorization of aspect proposed by Comrie. And the main differences between perfective and imperfective forms could be explained, in terms of meaning, as it follows. The perfective aspect would indicate a look at the situation from outside, "presented as a complete event, without further subdivision into successive temporal phases," such as in John read that book yesterday (COMRIE, 1976:4). So, the perfective would have the effect of reducing a situation into a blob, i.e. the situation would be seen as a three-dimensional object with clearly circumscribed limits, although it might have internal complexity. On this note, Comrie (1976:21) clarifies: "it follows that perfectivity involves lack of explicit reference to the internal temporal constituency of a situation, rather than explicitly implying the lack of such internal temporal constituency."

At this point, it is worth bringing to notice the terminological distinction regarding the term 'perfective'. As Comrie (1976:12) himself states, many works by English-speaking linguists used the term 'perfective' as a synonym for 'perfect', which the author characterizes as "unfortunate," since it leads to a "conceptual confusion." Whatever the case might be, Quirk et al (2005) can be considered part of these 
linguists who adopt a different interpretation of the concepts of 'perfect' and 'perfectivity', since the authors use the term 'perfective' to refer to the Perfect aspect, as indicated in Section 1. So, we could affirm that perfectivity, in the sense Comrie presents it, is not assumed by the English grammar books analyzed in this paper.

Nonetheless, this omission of the idea of perfectivity in the English grammar books might be explained by the form-oriented paradigm they follow. As Comrie (1976:3) highlights: English would not have the perfective aspect if we consider having an aspect similar to not having a special verbal form to indicate it. However, according to the author, the difference between "was reading" and "entered" would indeed be one of imperfectivity versus perfectivity.

In other words, we may suggest that the Simple Past might provide a perfective or an imperfective point-of-view. Thus, presumably, this would be the idea meant by Biber et al (1999:452) when they introduced the existence of a so-called 'unmarked/simple aspect' ${ }^{5}$, as we can see in the examples transcribed from their original work:

tense: present or past (e.g. see(s) versus saw)

aspect: unmarked/simple, perfect, progressive (e.g. sees versus has seen versus is seeing), or perfect progressive (e.g. has been seeing)

The term 'unmarked' is used as a synonym of 'simple', which seems to indicate that the lack of markedness of the Simple Past and the Simple Present might correspond to either the perfective or the imperfective point-of-view. In contrast to the look of the situation from the outside of the perfective aspect, the imperfective would indicate a look at the situation from inside: the event would be opened up, making "explicit reference to the internal temporal structure of a situation" (COMRIE, 1976:24). So, the use of the Simple Past of the verb "to study", for example, might convey a perfective aspect in a sentence such as "John studied a lot yesterday", in the sense that the event is

5. For further discussion, we suggest verifying Hirtle (1967, 1988), which relates simple aspect to the view of having necessary and sufficient conditions of the event satisfied, and Leech's (2004: 3-4) Introduction, outlining non-perfect and non-progressive forms 
reduced into a blob, or an imperfective aspect, as in the example "John studied a lot when he was a child", in which the internal constituency of this habitual action is brought up.

Habitualness is one of the notions associated with Imperfectivity, although this concept is not explicitly mentioned in the grammar books. However, the internal constituency of a situation might also be highlighted through the idea of continuity, as provided by the use of the progressive form in English, such as in "John is reading now". Nevertheless, it is worth noticing that the notion of continuity is not exclusively related to the progressive verb form. The Brazilian progressive form 'está lendo', for instance, is represented as 'está a ler' in European Portuguese. Both express the continuous aspect, but the latter is considered a non-progressive form.

As we have seen, the idea of perfect and progressive as basic aspects in the English grammar books here analyzed is differently configured in Comrie's proposal. The subdivision of the basic aspects proposed by Comrie can be contemplated in Figure I.

Figure I - Classification of aspectual oppositions, according to Comrie $(1976: 25)$

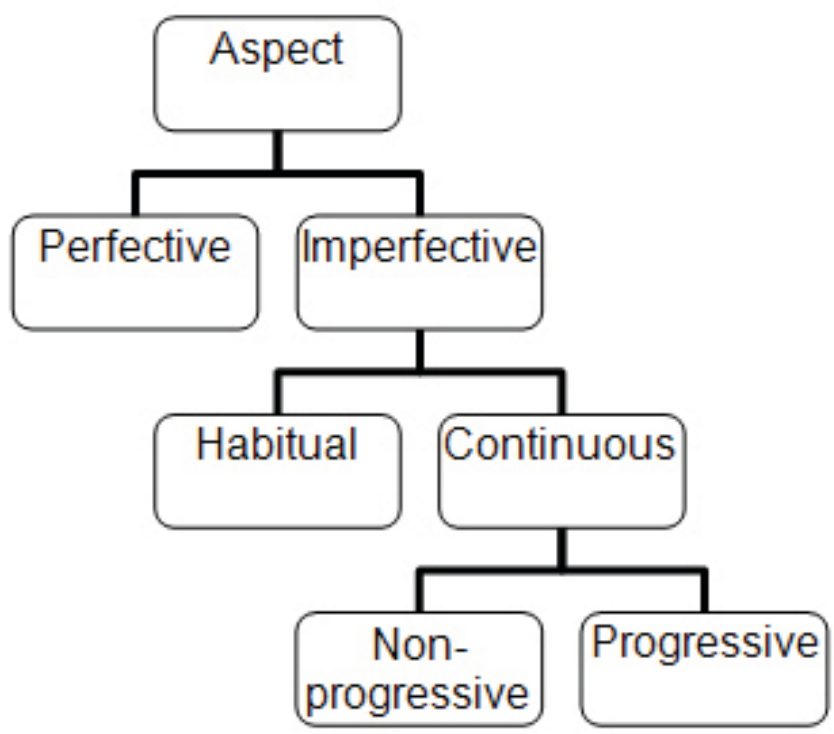


According to Comrie (1976), there would be different groupings of the semantic distinctions illlustrated in Figure I. Imperfectivity may be expressed in some languages by a single category, whereas other languages provide distinct categories to express its habitual or continuous reading. For instance, in the past tense of the English language, there are separate Habitual and Continuous aspects, e.g. John used to eat here; John was eating, respectively. Otherwise, the Simple form provides no further distinction of aspect, with a choice between the Imperfective Habitual or the Perfective, as we have previously illustrated. So, the sentence John ate here may have a perfective or an imperfective habitual meaning.

This grouping of semantic distinctions are differently conceived in other languages. In the past tense of the Brazilian Portuguese, for example, the Pretérito Perfeito only conveys the Perfective aspect, e.g. João comeu aqui. In contrast, the Pretérito Imperfeito may convey the Habitual or the Continuous aspect, e.g. João comia aqui (antigamente); João comia aqui (quando a bomba explodiu), excluding though a perfective interpretation. These groupings of semantic distinctions in English and in Portuguese can be better visualized in Table IV.

Table IV - Semantic Distinctions in English and in Portuguese

\begin{tabular}{|l|l|l|}
\hline Semantic Distinctions & English & Portuguese \\
\hline Imperfective Habitual & $\begin{array}{l}\text { John used to eat here } \\
\text { John ate here (when he was } \\
\text { a child) }\end{array}$ & $\begin{array}{l}\text { João comia aqui } \\
\text { (antigamente) }\end{array}$ \\
\hline Imperfective Continuous & $\begin{array}{l}\text { John was eating here } \\
\text { (when the bomb went off) }\end{array}$ & $\begin{array}{l}\text { João estava comendo aqui } \\
\text { Joomia aqui (quando a } \\
\text { bomba explodiu) }\end{array}$ \\
\hline Perfective & John ate here (yesterday) & João comeu aqui (ontem) \\
\hline
\end{tabular}

Still regarding Figure I, it is clear that Comrie does not consider the Perfect a basic aspect, diverging from the English grammar authors. However, we may assume that they take for granted a classification somehow parallel to Comrie's proposal, since his PerfectiveImperfective opposition would correspond to the Perfect-Progressive aspectual opposition presented by the other authors. 
Finally, regarding the Perfect aspect, we would like to provide a much more comprehensive analysis, but we will need to leave this to a new paper. In a nutshell, we may state that the idea of the Perfect indicating the relationship between two time frames or the relevance of a situation are compatible to Comrie's definition. Nonetheless, Comrie (1976: 56) goes further and presents particular types of perfect, i.e. the perfect of result, the experiential perfect, the perfect of persistent situation, and the perfect of recent past.

\section{Conclusion}

The teaching/learning process related to aspect in English as a foreign language has been considered a challenge for international students. We acknowledge the existence of major referential books which provide interesting analysis on the difficulties faced in this learning process (cf. CELCE-MURCIA, LARSEN-FREEMAN, 1999; SWAN, SMITH, 1987). However, it is well known that most students - and even English teachers - can only resource to the traditional descriptive grammars. One possible explanation is the accessibility and pervasion of this material both in academic and non-academic contexts.

In our practice as professors of English dealing with this kind of material, we have noticed that the concept of aspect has been didactically described and formulated in various ways, which makes the topic become even more complex. Given the relevance of the theme, in this paper, we reviewed and compared the various ways aspect is presented in traditional descriptive grammar books.

In the analysis, it comes into view that, although aspect is approached in a considerably comprehensive way in four out of five grammar books analyzed here, there is consistent variance in the categorization and terminology adopted by the authors which might cause confusion for students or teachers who resource to them. In order to thoroughly examine these categories and terminologies, we have contrasted them with an alternative perspective based on crosslinguistic studies, thus, more focused on meaning. 
Using Comrie (1976) as a benchmark, it is noticeable that the definition of aspect is common sense in the literature, always referring in some way to the speaker's point of view associated with the internal time of the situation. However, the most valuable contribution of this endeavor has been to compare the classification of aspectual oppositions, illustrating the main conceptual differences and similarities among the different authors.

Regarding the terminology adopted in the description of these points of view, some of the secondary variance relies on the use of the term 'perfective' as a synonym for 'perfect.'We highlight that this confusion might be related to the debate on whether the English language would have the perfective aspect, since there is no special verb form to indicate it. Since perfective is considered a basic aspect by Comrie (1976) due to its notability in language systems, this disambiguation may be of considerable importance for students and teachers of English as a foreign language.

Most importantly, Comrie's basic aspects and its subdivisions may help understand the proposals of 'unmarked/simple aspect' opposition and 'non-perfective'/"non-progressive' neutral aspects, by Biber et al (1999) and Quirk et al (2005), respectively. They also help clarify the categorization of aspect in two classes - progressive and perfect offered by Carter \& McCarthy (2006) and Greenbaum (1996). Based on this comparison, we may assert that the classification of the former assume that aspect is present in every verb form and the latter approach aspect strictly based on compound forms (auxiliary + main verb) complementary to the simple forms, which would only mark tense.

In conclusion, we believe this contrastive analysis contributes to a richer debate on the categorization offered by these English grammar books with an alternative approach offered by studies more focused on meaning. Furthermore, this clarification might enable students and teachers of English as a foreign language to reflect more deeply upon aspect, comparing aspectual forms and meanings in English and in their mother tongue. 


\section{References}

BIBER, Douglas et al. 1999. Longman Grammar of Spoken and Written English. Harlow: Pearson Education.

CARTER, Ronald; MCCARTHY, Michael. 2006. Cambridge Grammar of English: a comprehensive guide. Cambridge: Cambridge University Press.

CELCE-MURCIA, Marianne; LARSEN-FREEMAN, Diane. 1999. The grammar book: an ESL/EFL teacher's course, 6th ed.

COLLINS, William. 2005. Collins COBUILD English Grammar. Glasgow: Harper Collins, $2^{\text {nd }}$ ed.

COMRIE, Bernard. 1976. Aspect: an introduction to the study of verbal aspect and related problems. New York: Cambridge University Press.

DAHL, Östen. 1985. Tense and aspect systems. Oxford: Blackwell.

GREENBAUM, Sidney. 1996. The Oxford English Grammar. New York: Oxford University Press.

HIRTLE, Walter. 1967. The Simple and Progressive Forms. Quebec: Presses de I'Université Laval.

HIRTLE, Walter. 1988. Events, Time and the Simple Form. Revue Québécoise de Linguistique, volume 17, number 1, 85-105. doi:10.7202/602615ar. Available at https://www.erudit.org/en/ journals/rq1/1988-v17-n1-rq12929/602615ar/

LEECH, Geoffrey. 2004. Meaning and the English Verb. Harlow: PearsonLongman, $4^{\text {th }}$ ed.

QUIRK, Randolph et al. A grammar of Contemporary English. Harlow: Longman, $9^{\text {th }}$ ed., 1980.

SMITH, Carol. 1991. The Parameter of Aspect. Dordrecht: Kluwer Academic Publishers.

Recebido em: 03/06/2018

Aprovado em: 20/08/2019 